\title{
ENHANCED PERFORMANCES OF HIGH FREQUENCY PULSED DIRECT CURRENTSHIELDED METAL ARC WELDING
}

\author{
BuddhadevBagchi \\ Sr. Dy. General Manager, Power Training Institute, L\& T Power, Vadodara, Gujarat, India, \\ buddhadev.bagchi@Intpower.com
}

\begin{abstract}
In practice the pulsedDirect Current (DC) welding is associated with Tungsten Inert GasArc welding process. This paper presents a novel Direct Current Arc Welding Technology named as High Frequency Pulsed Direct Current Shielded Metal Arc Welding (HF Pulsed DC SMAW) in whichthe square pulsed Direct Current superimposed by the high frequency Alternating Current is developed for welding any metal joint. This specialized Direct Current Arc Welding Technology uses one High Frequency Unit (HF) and one half-wave rectifier (Pulsar) with conventional welding machine. The performances of this technology have beeninvestigated and compared with the conventional Steady Direct Current Shielded Metal Arc Welding (DCSMAW) technology for the study on energy consumption, thermal gradient, heat input, metallurgical characteristics, weld quality and consumption of filler metal. HF Pulsed DC SMAW technology has been found superior to the conventional steady DC SMAW technology in respect toall the above parameters. Accordingly, instead of using steady DC SMAW technology, the HF Pulsed DC SMAW can be commercially used for any metal fabrication, manufacturing and maintenance of pressure vessels \& pressure parts and any other applications.
\end{abstract}

Keywords: Welding, Direct Current, High Frequency, Pulsed.

\section{INTRODUCTION}

Conventional Steady Direct Current Shielded Metal Arc Welding (SMAW) is an established Welding Technology in industrial sectors. It is an indispensable engineering tool in industries and also has enormous applications in industrial projects of power plants, chemical plants, Steel plants, process plants and many others industries. But conventional DC SMAW process has the disadvantages of:
i. High consumption of electrical energy,
ii. Burning off the base metals at the beginning of welding,
iii. Non-uniform weld bead,
iv. High temperature gradient and overheating of base metals resulting in High Grain sizes in HAZ causing metallurgical disorder.
v. High consumption of weld metal

The above demerits are not desirable in any welding product especially for boiler pressure parts, pipes, headers, tubes, pressure vessel etc.

High Frequency Pulsed Direct Current ShieldedMetal Arc Welding Process has been developed to mitigate all the above mentioned demerits by implementing squarely pulsed welding current between peak current for welding at the beginning of each weaving and background current at the ending of the same weaving. This pulsed welding current has also been superimposed by high frequency $(5000 \mathrm{~Hz})$ current.

\section{PULSED DIRECT CURRENT CHARACTERISTICS}

Direct Current can be squarely pulsed between two levels (Peak Current \& Background Current) at short or long time intervals, by using transistorized power source with convertor and single half wave rectifier. The single half wave rectifier is connected parallel with the three-phase bridge convertor to produce pulsed Direct Current with different desired pulse frequencies and weld bead width.

The Fig.-1a \& Fig.1b illustrate the comparison of the square pulsed direct current and conventional steady direct current (non-pulsed). Ignoring the presence of harmonics in the nonsinusoidal alternating current components in the direct current it can be presumed that the welding current in conventional DC SMAW always remains constant at the high value throughout the arc on time (welding period) as shown in Fig. 1(a). Whereas current in case of HF Pulsed Direct CurrentSMAW is variablein squarepulsing as shown in Fig.1b. 


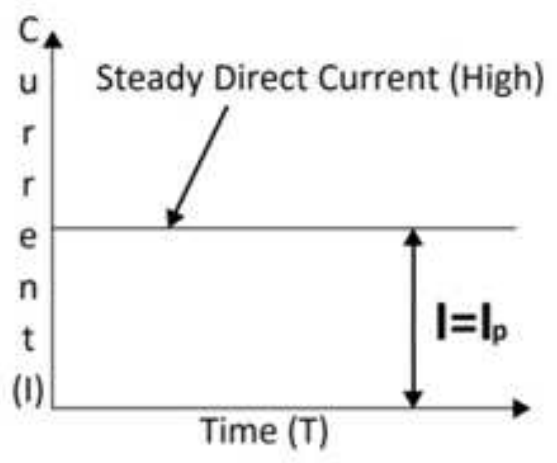

(a) Conventional Steady Direct Current SMAW

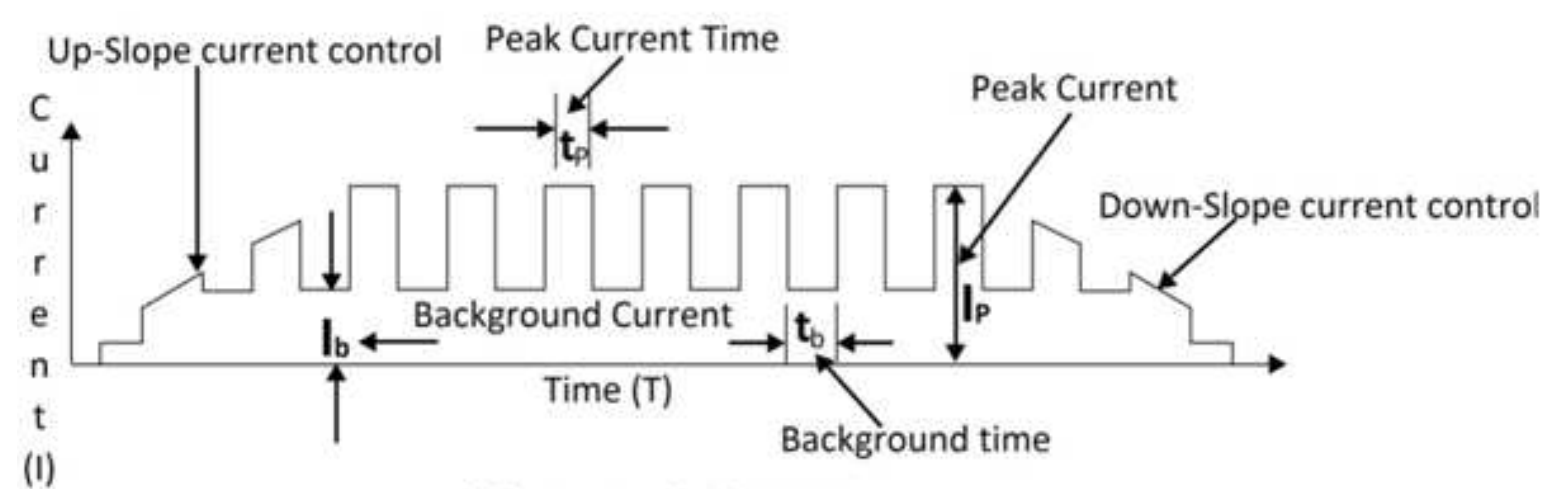

(b) DC HF Pulsed SMAW

Fig-1: Comparison of conventional Steady Direct Current \& Square Pulsed Direct Current

The following parameters are set before starting of welding by the HF Pulsed DC SMAW:
a) Peak Current $\left(I_{p}\right)$ in Amps.
b) Peakcurrent Time or duration $\left(t_{p}\right)$ in sec.
c) BackgroundCurrent $\left(\mathrm{I}_{\mathrm{b}}\right)$ in Amps.
d) Backgroundcurrent time or duration $\left(\mathrm{t}_{\mathrm{b}}\right)$ in sec.
e) Upslope Time in sec.
f) Downslope Time in sec.

The Peak Current and its duration are the functions of the plate thickness and thermal properties of the metal. The peak current time also depends on the plate thickness and selection of width of the weld bead. The background current influences the cooling rate and its duration should be selected properly to allow the cooling of the weld bead between peak pulses.

The average welding current $\left(\mathrm{I}_{\mathrm{av}}\right)$ valid for rectangular pulse wave is

$$
\mathrm{I}_{\mathrm{av}}=\frac{\mathrm{I}_{p} \mathrm{t}_{p}+\mathrm{I}_{b} \mathrm{t}_{b}}{\left(t_{p}+t_{b}\right)}
$$

$$
\mathrm{I}_{\mathrm{av}}=\frac{\mathrm{I}_{p} \mathrm{t}_{p}+\mathrm{I}_{b} \mathrm{t}_{b}}{\mathrm{t}}
$$

Where ' $\mathrm{t}$ ' is the pulse cycle time $=\left(t_{p}+t_{b}\right)$

In conventional steady SMAW process, welding current always remains constant at high value (I) equal to $\left(\mathrm{I}_{\mathrm{p}}\right)$ throughout the welding period.

\section{VARIABLES FOR HF PULSED DC SMAW PROCESS}

In HF PulsedDC SMAW there are two categories of variables as mentioned bellow, which affect the performances of the welding in all respects:
a) Primary Variables
b) Distinct Variables

\subsection{Primary Variables}

In conventional DC SMAW the primary variables are arc voltage /arc length \& welding/travel speed only; whereas in case of HF pulsedDC SMAW apart from arc voltage /arc 
length \& welding/travel speed, the other primary variables are peak current, background current, peak current timing, background current timing and pulse frequency. During the experiment the effects of these additional variables have been studied and compared with the conventional Steady DC SMAW for the following parameters:
i) Energy consumption during welding,
ii) Formation of weld bead by influencing the depth of penetration,
iii) Bead width, bead height bead quality
iv) Consumption of filler metal (electrodes)
v) Metallurgical properties of weld bead \& heat affected zone (HAZ).
vi) Spatter level.

The pulsing behavior of current brings metal/zones to be welded to the melting point during peak current and continues upto peak current time-period and allows this weld zone to cool \& solidify during background current time-period.

\subsection{Distinct Level Variable for Pulsed SMAW}

\section{Process}

The distinct level variables for Pulsed SMAW Process are Upslope current \&time, Downslope current \& time as shown in the fig. $1 \mathrm{~b}$ and the superimposed high frequency additional low value current. Half wave rectifier (Pulsar) and H.F unit are used to control these variables for controlling the metal burning and crater at beginning and end of the welding respectively.

\section{METHODOLOGY}

\subsection{Circuit Diagrams \&Equipment}

The Fig.2 shows the circuit diagram of the conventional Steady DC SMAW process using a DC Welding Rectifier. in case of Steady DC SMAW process electrode holder is directly connected with the negative terminal of the welding machine whereas in case of High Frequency PulsedDC SMAW Process the electrode holder is connected with the negative terminal of the welding machine via a HF Unit. In the circuit diagram a half-wave rectifier named as pulsar is connected parallel with the power source by the remote control cables.

Table 1Equipment used in experiments \& their specifications

\begin{tabular}{|c|c|c|}
\hline $\begin{array}{l}\text { Welding } \\
\text { Process }\end{array}$ & $\begin{array}{l}\text { Power } \\
\text { Source }\end{array}$ & Auxiliary Equipment \\
\hline $\begin{array}{l}\text { HF Pulsed DC } \\
\text { SMAW }\end{array}$ & $\begin{array}{l}\text { DC Rectifier } \\
\text { AC Input } \\
415 \mathrm{~V} 50 \mathrm{~Hz}, \\
3 \phi \\
18 \mathrm{KVA} \\
\text { DC Output } \\
O C V-80 \mathrm{~V} \\
\text { Max. } \\
\text { continuous } \\
\text { current at } \\
100 \% \text { Duty } \\
\text { Cycle-200A }\end{array}$ & $\begin{array}{l}\text { a) Half Wave } \\
\quad \text { Rectifier (Pulsar) } \\
\text { Supply Voltage-240V } \\
\text { 50Hz } 1 \phi \\
\text { Peak current-20 to } \\
\text { 300Amps } \\
\text { Background current-20 to } \\
\text { 100Amps } \\
\text { Peak Time- } 0.1 \text { to } 9.9 \\
\text { secs. } \\
\text { Background time-0.1 to } \\
\text { 9.9 secs. } \\
\quad \text { b) High Frequency } \\
\quad \text { (HF) Unit } \\
\text { Supply Voltage-240V } \\
\text { 50Hz 1 } \phi \\
\text { Max. Welding current- } \\
\text { 300Amps. }\end{array}$ \\
\hline $\begin{array}{l}\text { Conventional } \\
\text { SMAW }\end{array}$ & --Do-- & $-\cdots$ \\
\hline
\end{tabular}

The Fig. 3 shows the circuit diagram of the devised High Frequency Pulsed DC SMAW Process using the same welding machine. Both the processes follow the straight polarity. But

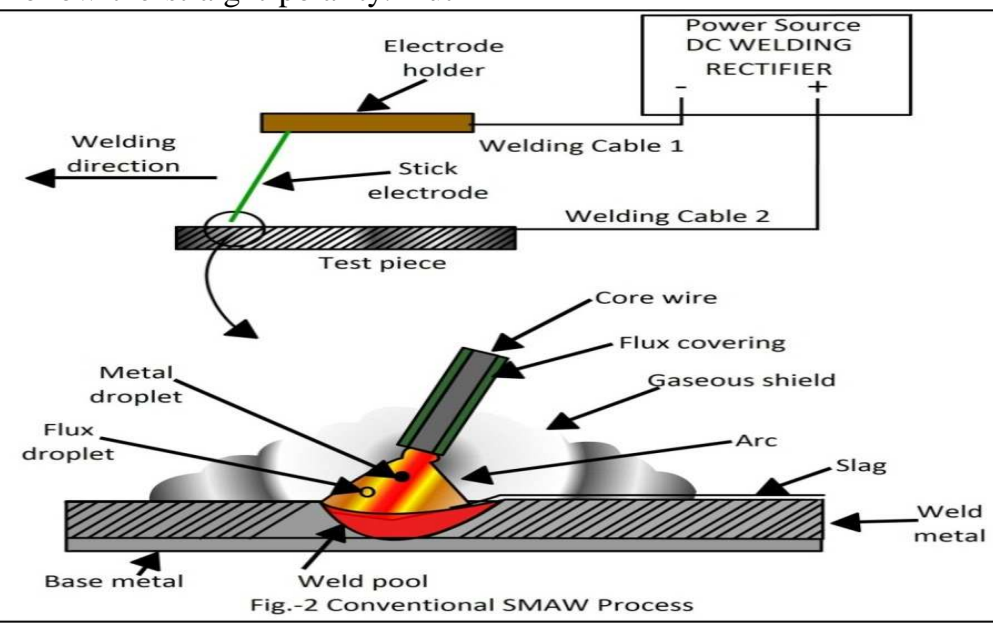




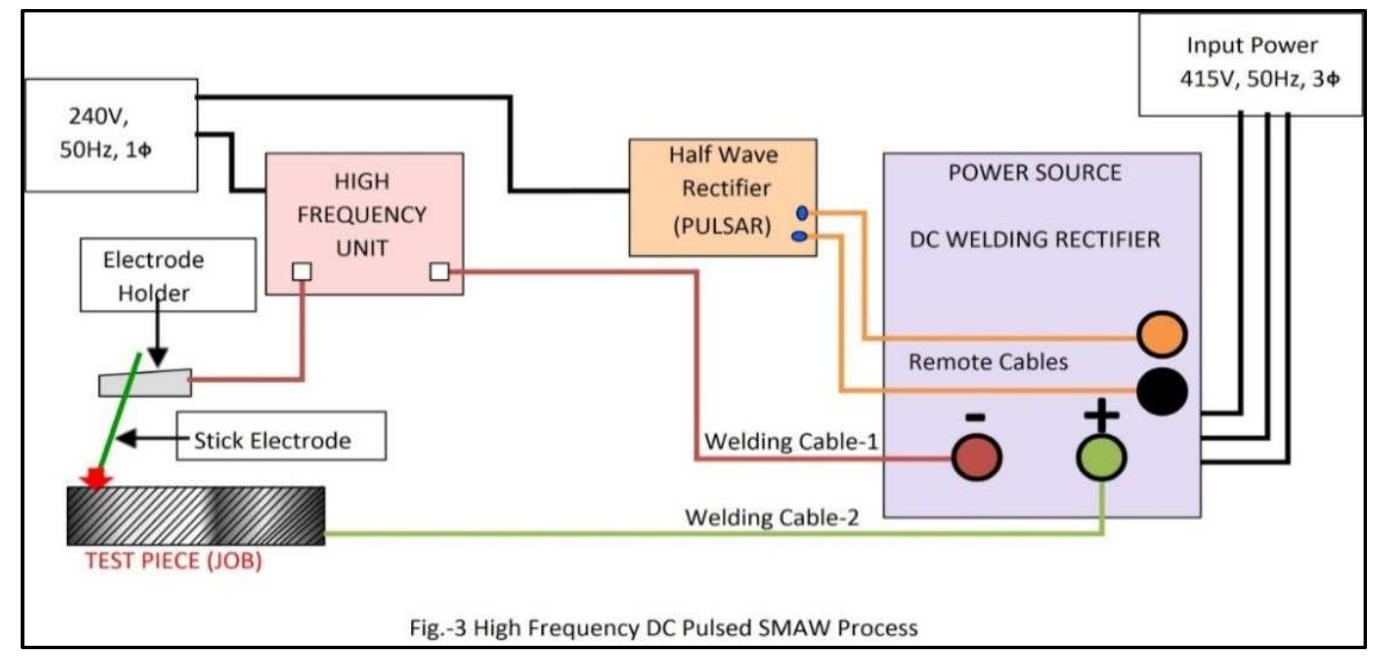

In this research work experimental welding was done on several numbers of mild steel test pieces of different sizes at different welding parameters as mentioned in the table $2 \& 3$, using electrodes AWS6013 of sizes $2.4 \mathrm{~mm}, 3.2 \mathrm{~mm}, 4.06 \mathrm{~mm}$ $\& 5 \mathrm{~mm}$.

\subsection{Studies onEffects of Pulsing Current on Welding:}

From the equation 1 the average welding current $\left(I_{a v}\right)$ during HF Pulsed DC SMAW process is obtained as

$$
\mathrm{I}_{\mathrm{av}}=\frac{\mathrm{I} p \mathrm{t}_{p}+\mathrm{I}_{b} \mathrm{t}_{b}}{\mathrm{t}}, \mathrm{t}=\left(t_{p}+t_{b}\right)
$$

As the background current $\left(\mathrm{I}_{\mathrm{b}}\right)$ is very less as compared with peak current and only for maintaining the arc, mathematically it can be stated that the average welding current $\left(\mathrm{I}_{\mathrm{av}}\right)$ in $\mathrm{HF}$ Pulsed DC SMAW is lesser than the peak welding current $\left(I_{p}\right)$ and also welding current(I) in conventional SMAWfor the same thickness of metal plate.

The experimental study and its comparative result as indicated in the Table- 2 and Table- 3 prove the above statement.

Table 2Welding data for conventional Steady DC SMAW

\begin{tabular}{|c|c|c|c|c|}
\hline $\begin{array}{c}\text { Test piece } \\
\text { No. }\end{array}$ & $\begin{array}{c}\text { Test Piece } \\
\text { Size }\end{array}$ & $\begin{array}{c}\text { Welding current set } \\
\left(\mathbf{I}=\mathbf{I}_{\mathbf{P}}\right) \mathbf{A m p}\end{array}$ & $\begin{array}{c}\text { Welding voltage } \\
(\text { Volts })\end{array}$ & $\begin{array}{c}\text { Total Time-T } \\
(\mathbf{s e c s} \text { ) }\end{array}$ \\
\hline 1 & $150 \mathrm{~mm} \times 50 \mathrm{~mm} \times 3 \mathrm{~mm}$ & 95 & 23.8 & 150 \\
\hline 2 & $150 \mathrm{~mm} \times 50 \mathrm{~mm} \times 5 \mathrm{~mm}$ & 110 & 24.4 & 230 \\
\hline 3 & $150 \mathrm{~mm} \times 50 \mathrm{~mm} \times 8 \mathrm{~mm}$ & 150 & 26 & 340 \\
\hline 4 & $150 \mathrm{~mm} \times 50 \mathrm{~mm} \times 10 \mathrm{~mm}$ & 175 & 27 & 420 \\
\hline
\end{tabular}

Table 3:Welding data for HF Pulsed DC SMAW

\begin{tabular}{|c|c|c|c|c|c|c|c|c|}
\hline $\begin{array}{c}\text { Test } \\
\text { piece } \\
\text { No. }\end{array}$ & $\begin{array}{l}\text { Test Piece } \\
\text { size }\end{array}$ & $\begin{array}{c}\text { Peak } \\
\text { current } \\
\text { Set-I }_{\mathrm{p}} \\
(\text { Amps })\end{array}$ & $\begin{array}{l}\text { Peak } \\
\text { time } \\
\text { Time- } \\
\text { set- } t_{p} \\
(\text { secs.) }\end{array}$ & $\begin{array}{l}\text { Back- } \\
\text { ground } \\
\text { current } \\
\text { Set-I }{ }_{b} \\
\text { (Amps.) }\end{array}$ & $\begin{array}{l}\text { Back- } \\
\text { ground } \\
\text { Time } \\
{\text { set- } \mathrm{t}_{\mathrm{b}}}^{\text {(secs.) }} \\
\end{array}$ & $\begin{array}{l}\text { Average welding } \\
\text { current-Amp. } \\
\mathrm{I}_{\mathrm{av}}=\frac{\mathrm{I} \mathrm{t}_{p}+\mathrm{I}_{b} \mathrm{t}_{b}}{\mathrm{t}}\end{array}$ & $\begin{array}{c}\text { Welding } \\
\text { voltage- } \\
\text { V } \\
\text { (Volts) }\end{array}$ & $\begin{array}{c}\text { Total } \\
\text { Time- } \\
\text { T } \\
\text { (secs.) }\end{array}$ \\
\hline 1 & $\begin{array}{c}150 \mathrm{~mm} \times 50 \\
\mathrm{~mm} \times 3 \mathrm{~mm}\end{array}$ & 95 & 1 & 20 & 0.5 & 70 & 23.8 & 160 \\
\hline 2 & $\begin{array}{c}150 \mathrm{~mm} \times 50 \\
\mathrm{~mm} \times 5 \mathrm{~mm}\end{array}$ & 110 & 1 & 20 & 0.5 & 80 & 24.4 & 247 \\
\hline 3 & $\begin{array}{c}150 \mathrm{~mm} \times 50 \\
\mathrm{~mm} \times 8 \mathrm{~mm}\end{array}$ & 150 & 1.5 & 20 & 0.5 & 117.5 & 26 & 340 \\
\hline 4 & $\begin{array}{l}150 \mathrm{~mm} \times 50 \\
\mathrm{~mm} \times 10 \mathrm{~mm}\end{array}$ & 175 & 1.5 & 20 & 0.5 & 136.25 & 27 & 430 \\
\hline
\end{tabular}


As per the Table- 3 the average welding current in all cases of HF Pulsed DC SMAW are lesser. Hence, it is proved that for welding the same size of metal plate, the average welding current $\left(\mathrm{I}_{\mathrm{av}}\right)$ in HF Pulsed DC SMAW < the welding current in conventional SMAW.

\subsection{Investigationon Result of Pulsing Current:}

The study reveals that lesser current due to pulsing in HF Pulsed SMAW significantly controls the management of the electrical energy \& thermal energy and produce better impacts on the welding as explained bellow:

\subsubsection{LowerElectrical Energy Consumption:}

For welding a metal joint by conventional SMAW process (non-pulse) in total time $\mathrm{T}$, the electrical energy consumption is

$\mathrm{E}_{\mathrm{NPDC}}=\mathrm{I} \times \mathrm{V} \times \mathrm{T} \mathrm{KWh} \ldots \ldots \ldots \ldots \ldots .2$
Where I is the welding current set and $\mathrm{V}$ is the voltage in $\mathrm{KV}$ during welding, which depends on the welding current, considering the arc length constant.

For welding the same joint by the HF Pulsed SMAW process in total time $\mathrm{T}$, the electrical energy consumption

$$
\mathrm{E}_{\mathrm{PDC}}=\mathrm{I}_{\mathrm{av}} \times \mathrm{V} \times \mathrm{T} \mathrm{KWh}, \mathrm{V} \text { in } \mathrm{KV} \ldots \ldots . .3
$$

$\mathrm{E}_{\mathrm{PDC}}<\mathrm{E}_{\mathrm{NPDC}}$

[As $\mathrm{I}_{\mathrm{av}}<\mathrm{I}$ and $\mathrm{I}=\mathrm{I}_{\mathrm{p}}$ for the same metal thickness]

Although total time (T) for welding each plate during $\mathrm{HF}$ Pulsed DC Welding is slightly higher, the energy consumption in HF PulsedDC SMAW process is lower than that of conventional SMAW process (non-pulse) for welding similar metal joint and considering the same welding arc on time.

The experimental study and its comparative result as indicated in the Table- 4 prove the above statement.

Table 4Electrical energy consumed

\begin{tabular}{|c|c|c|c|c|}
\hline $\begin{array}{c}\text { Test } \\
\text { piece } \\
\text { No. }\end{array}$ & Test piece Size & $\begin{array}{c}\text { Energy consumed by } \\
\text { conventional SMAW } \\
\mathrm{E}_{\mathrm{NP}}=\mathrm{I} \times \mathrm{V} \times \mathrm{T} \mathrm{KWh}\end{array}$ & $\begin{array}{c}\text { Energy consumed by } \\
\text { HF Pulsed DC SMAW } \\
\mathrm{E}_{\mathrm{P}}=\mathrm{I}_{\mathrm{av}} \times \mathrm{V} \times \mathrm{T} \mathrm{KWh}\end{array}$ & $\begin{array}{c}\text { Percentage of } \\
\text { energy saving }\end{array}$ \\
\hline 1 & $150 \mathrm{~mm} \times 50 \mathrm{~mm} \times 3 \mathrm{~mm}$ & 0.0942 & 0.074 & 21.44 \\
\hline 2 & $150 \mathrm{~mm} \times 50 \mathrm{~mm} \times 5 \mathrm{~mm}$ & 0.171 & 0.134 & 21.63 \\
\hline 3 & $150 \mathrm{~mm} \times 50 \mathrm{~mm} \times 8 \mathrm{~mm}$ & 0.368 & 0.297 & 19.29 \\
\hline 4 & $150 \mathrm{~mm} \times 50 \mathrm{~mm} \times 10 \mathrm{~mm}$ & 0.551 & 0.439 & 20.32 \\
\hline
\end{tabular}

Table 4 indicates that the electrical energy saving in HF Pulsed DC SMAW process is around 20\%. In an industrial project the average 10 nos. of welding machines are daily used with arc on time around $4.7 \mathrm{hrs}$ for each welding machine. Hence, electrical energy saving using DC HF Pulsed SMAW process is reasonably high and it is energy efficient.

\subsubsection{Lower Thermal Gradient and Heat Input in Weld Bead and HAZ:}

In this experiment both the welding were done on the MS metal plates of thickness $20 \mathrm{~mm}$. Heat inputs during welding for both conventional SMAW process and HF pulsed DC SMAW process resulted with the experimental data for Thermal Gradient as indicated in Table-5 and Table-6.
As per the experimental data it is observed that the curves of thermal gradient for Conventional Non-pulsed SMAW are steeper than that for HF pulsed DC SMAW Process due to higher heat value caused by application of constant high welding current ( $I=I p>I a v)$ throughout the welding period. The comparison of thermal gradient between HF-DC pulsed SMAW Process and Conventional steady SMAW process are shown in the Fig. 4a \& Fig. 4b.

So, the research work proves that the thermal gradient in case of HF pulsed DC SMAW is flatter and also the heat input for welding the same size plate by HF-pulsed SMAWprocess is comparatively lower than that of conventional steady DC SMAW process. 
Table 5 Experimental Data for Thermal gradient during Steady DC SMAW

\begin{tabular}{|c|c|c|c|c|}
\hline $\begin{array}{c}\text { Sl. } \\
\text { No. }\end{array}$ & Number of Run & $\begin{array}{c}\text { Temp. at point 10 mm } \\
\text { distance from Weld } \\
\text { Bead Centre }\left({ }^{\mathbf{C}} \mathbf{C}\right) \\
\text { Point-1 }\end{array}$ & $\begin{array}{c}\text { Temp. at point 20 mm } \\
\text { distance from Weld } \\
\text { Bead Centre }\left({ }^{\mathbf{0}} \mathbf{C}\right) \\
\text { Point-2 }\end{array}$ & $\begin{array}{c}\text { Temp.at point 30 mm } \\
\text { distance from Weld } \\
\text { Bead Centre }\left({ }^{\mathbf{0}} \mathbf{C}\right) \\
\text { Point-3 }\end{array}$ \\
\hline 1 & First Run & 420 & 150 & 140 \\
\hline 2 & Second Run & 465 & 160 & 155 \\
\hline 3 & Third Run & 470 & 170 & 165 \\
\hline 4 & Forth Run & 500 & 175 & 170 \\
\hline
\end{tabular}

Table 6 Experimental Data for Thermal gradient during HF Pulsed DCSMAW

\begin{tabular}{|c|c|c|c|c|}
\hline $\begin{array}{c}\text { Sl. } \\
\text { No. }\end{array}$ & $\begin{array}{c}\text { Number of } \\
\text { Run }\end{array}$ & $\begin{array}{c}\text { Temp. at point 10 } \mathbf{~ m m} \\
\text { distance from Bead } \\
\text { Centre }\left({ }^{\mathbf{0}} \mathbf{C}\right)-\text { Point-1 }\end{array}$ & $\begin{array}{c}\text { Temp. at point 20 } \mathbf{~ m m} \\
\text { distance from Bead } \\
\left.\text { Centre( }{ }^{\mathbf{0}} \mathbf{C}\right), \text { Point-2 }\end{array}$ & $\begin{array}{c}\text { Temp. at point } \mathbf{3 0} \mathbf{~ m m} \\
\text { distance from Bead } \\
\left.\text { Centre( }{ }^{\mathbf{0}} \mathbf{C}\right) \text {, Point-3 }\end{array}$ \\
\hline 1 & First Run & 325 & 85 & 75 \\
\hline 2 & Second Run & 365 & 100 & 85 \\
\hline 3 & Third Run & 370 & 135 & 95 \\
\hline 4 & Forth Run & 390 & 138 & 115 \\
\hline
\end{tabular}

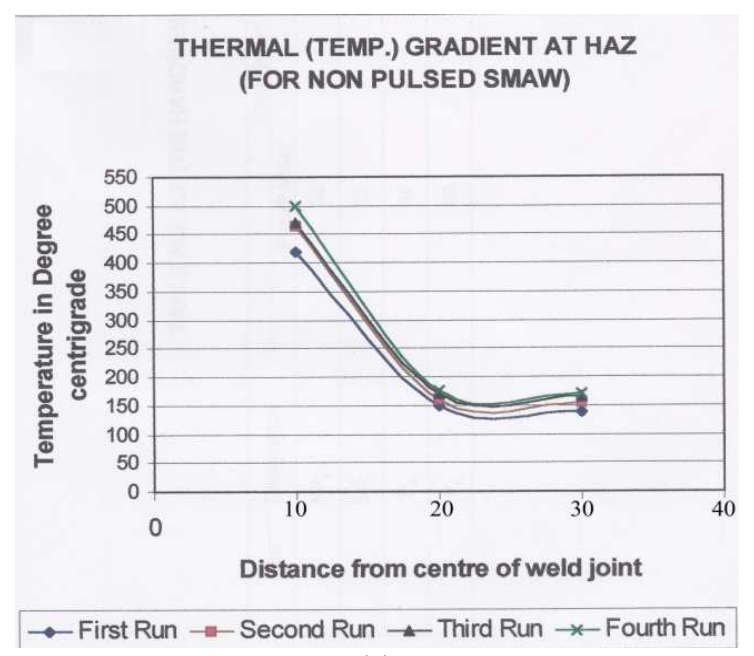

(a)

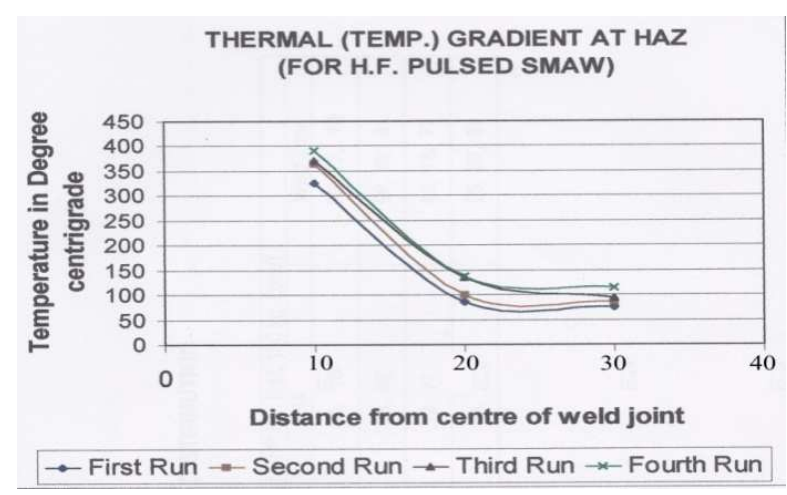

(b)

\subsubsection{Improved Metallurgical Properties of the Weld} Joint

This metallurgical investigation has also given very good promising results. Considering the effectsof current (steady \&pulsing), Thermal Gradient(steeper\& milder) and heat input (higher \& lower) in case of Steady Non-pulsed DC SMAW and HF pulsed DC SMAW the microstructural study was made to identify any improved metallurgical properties of theweld joint.. In the experiment small samples from all the welded plates of both the welding processes, containing parent metal, HAZ and weld bead were taken and prepared for examinations. The samples were etched in $2 \%$ Nital reagent and structures were revealed by optical microscope above 160X magnification.The various micrographs obtained at $160 X$ are shown in the Fig. 5, Fig.6 and Fig.7. The interpretations of micrographs are mentioned in Table-7.

Fig.4 Thermal Gradient at different positions of Heat Affected Zone 


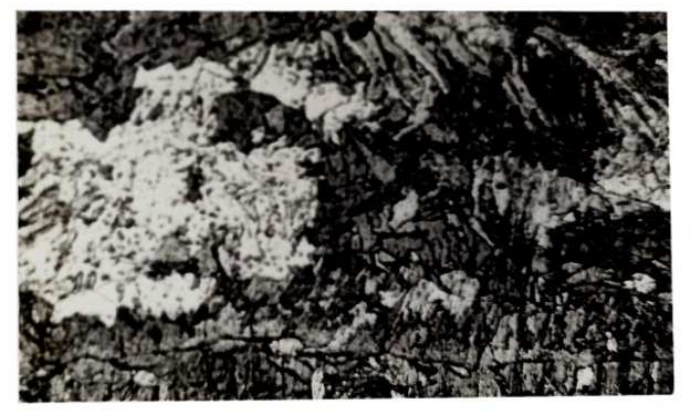

a) Steady Non-pulse DC Welding

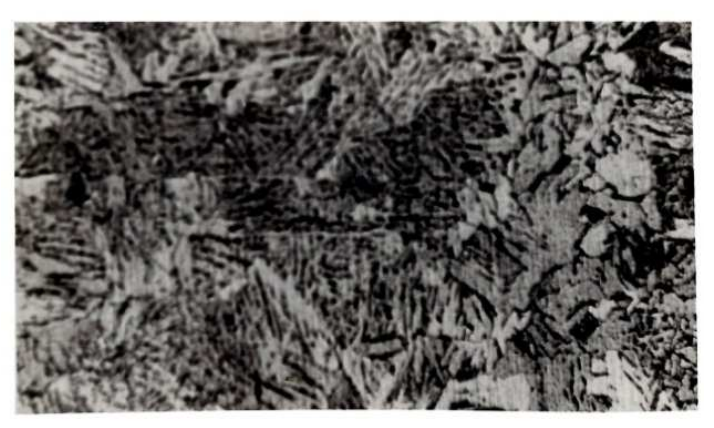

b) HF Pulsed DC Welding

Fig. 5Microstructures of Weld Metal

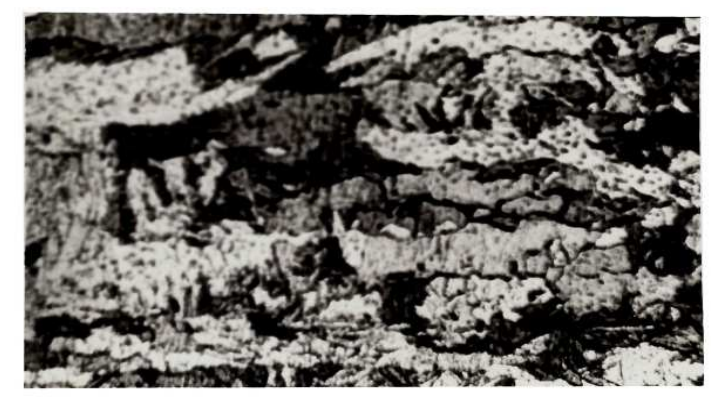

a) Steady Non-pulse DC Welding

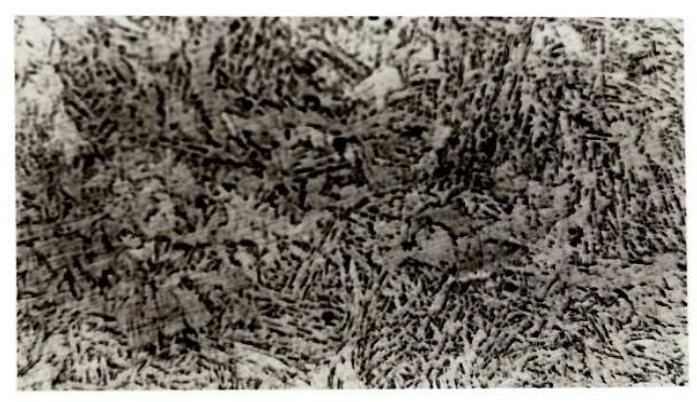

b) HF Pulsed DC Welding

Fig. 6Microstructures of weld metal near HAZ

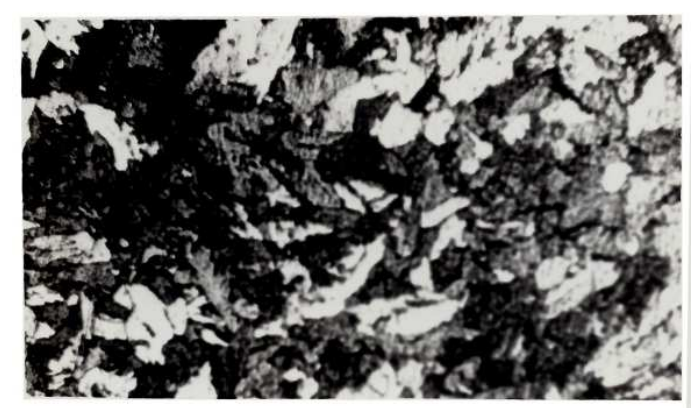

a) Steady Non-pulse DC Welding

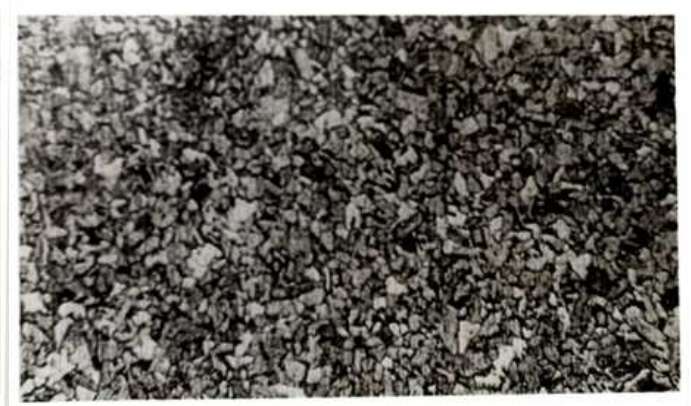

b) HF Pulsed DC Welding

Fig. 7 Microstructures of Parent Metal 
Table-7: Interpretation of Micrographs

\begin{tabular}{|l|l|l|l|l|l|}
\hline Sl. No. & Fig. No. & Reference Zone & Steady DC SMAW & HF Pulsed DC SMAW \\
\hline 1. & $5-a$ \& 5-b & Weld Metal & $\begin{array}{l}\text { Coarsening of original } \\
\text { austenite } \\
\text { transformed grain } \\
\text { ferrite and some colonies of } \\
\text { pearlite }\end{array}$ & $\begin{array}{l}\text { Columnar smaller grains of } \\
\text { ferrite \& pearlite }\end{array}$ \\
\hline 2 & 6-a \& 6-b & $\begin{array}{l}\text { HAZ nearer to } \\
\text { weld metal }\end{array}$ & $\begin{array}{l}\text { Coarsening of non-uniform } \\
\text { ferrite \& pearlite grains }\end{array}$ & $\begin{array}{l}\text { Smaller grains of ferrite \& } \\
\text { pearlite }\end{array}$ \\
\hline 3 & 7-a \& 7-b & $\begin{array}{l}\text { Parent metal } \\
\text { nearer to HAZ }\end{array}$ & $\begin{array}{l}\text { Coarse multi grains of ferrite } \\
\text { \&pearlite }\end{array}$ & Smaller sizes equiaxed grains \\
\hline
\end{tabular}

The Table 7 indicates that in case of HF Pulsed DC SMAW the grain sizes of microstructures at different zones of weld joint are noticeably smaller than that of conventional SMAW as shown in the Fig.5, Fig.6 and Fig.7. These smaller grains of microstructures of HF Pulsed DC SMAW are the indication of the improved metallurgical characteristics and better physical properties in regard to strength, toughness and surface quality of weld joint.

\subsubsection{Lower Consumption of Filler Metal \&Better Quality Weld Bead}

During welding metal plates by HF Pulsed DC SMAW process the following parameters have been controlled:
i) Peak current control
ii) Peak current time control
iii) Background current control
iv) Background current control

The above parameters automatically control electrode manipulation during welding which in turn control filler metal deposition and width of weld beads. The Fig. 8(a) and Fig. 8(b) show the welding joints of conventional DC SMAW and HF Pulsed DC SMAW processes respectively. In the welding joints of conventional DC SMAW as shown in the Fig. 8(a) the weld beads are not uniform and havepoor quality \& shape; they have extra filler metal deposition.It is clear that there was no control over the electrode manipulation, filler metal deposition and spatter during welding. Where as in case welding joints by HF Pulsed DC SMAW as shown in the Fig. 8(b) the weld beads are smooth and uniform. Also they have good quality, good shape, less spatter level and no extra filler metal deposition.

It has been observed that for welding the same size of plates by both the welding processes, the filler metal deposition in case of DC HF Pulsed SMAW is $20 \%$ lesser than that of conventional DC SMAW due to pulsed current control, control over the electrode manipulation and better spatter control. 


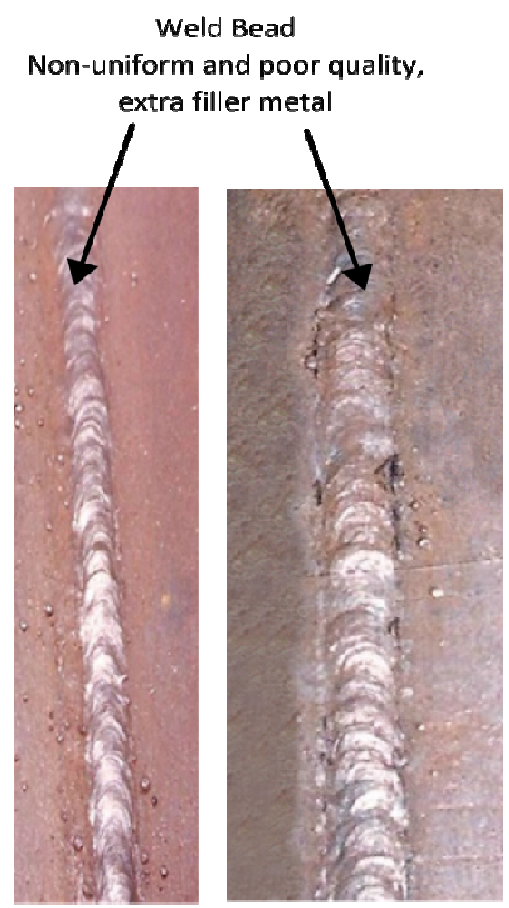

(a) steady DC SMAW

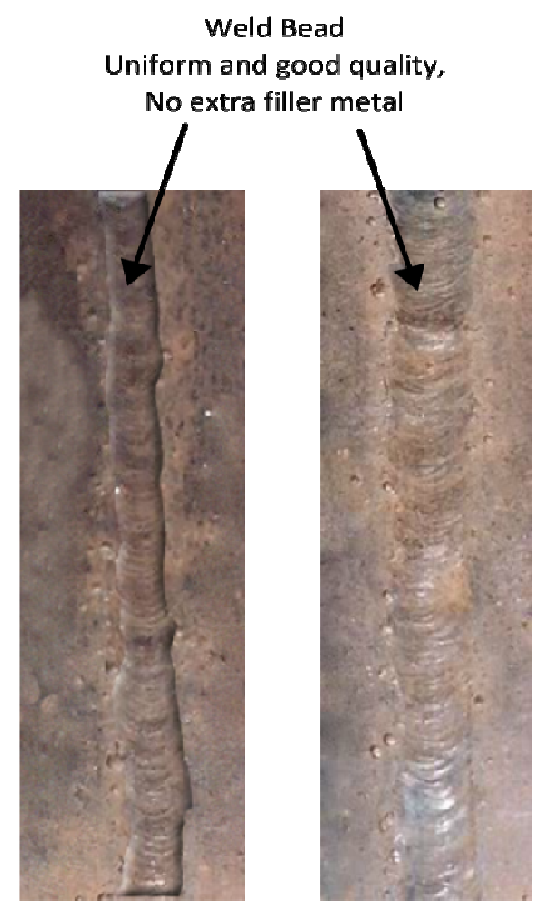

(b) HF DC SMAW

Fig. :8 Welding Joints

\section{OTHER EFFECTS OF HIGH FREQUENCY DC PULSED CURRENT}

The High Frequency unit helps to jump the welding current from tip of the electrode to the job for arc creation. It eliminates striking of the metal by electrode. Therefore, there is no burning off of metal at initial stage of welding. In case of the HF pulsed DC SMAW the initial current \& end current can be controlled precisely which eliminates end crater formation. But in case of non-pulsed DC SMAW there is no initial or final current control and so there is a chance of crater formation.

\section{CONCLUSIONS}

The studies of this research work show that HF Pulsed DC SMAW process is better than the conventional Steady DC SMAW process and it has the following advantages:

a) Lowerconsumption of electrical energy

b) Less consumption of filler metals/electrodes.

c) Low heat Input causing lower thermal gradient

d) Improved metallurgical properties

e) Better physical properties of welding joint

f) Better surface quality

The above advantages can be useful in any metal fabrication, critical piping, pressure vessels and all other applications using conventional Steady DC SMAW. Hence, the commercial application of High Frequency Pulsed Direct
Current Shielded Metal Arc Welding is suggested in industry in all place of conventional Steady Direct Current Shielded Metal Arc Welding.

\section{ACKNOWLEDGEMENTS}

[1]. I acknowledge the inspiring guidance of Dr. N. R. Dey, Ex. Professor and Prof. J. N. Das, Ex. Professor of NIT, Durgapur in devising this research work.

[2]. Iacknowledge continuous guidance and support of Mr. M. Arunachalam, Dean, Power Training Institute, L \& $\mathrm{T}$ Power,and Vadodara for writing this research paper.

[3]. I admit full support of Mr. S. K. Nag, Ex. Director, NPTI, Durgapur for doing this work on welding technology

\section{REFERENCES}

[1].Jean Cornu, “Advanced Welding System- TIG \& Related Welding”,Jaico Publishing House, 1994- pages 59-64

[2]. Little Richard L, Welding and Welding Technology", Tata McGraw-Hill, pages-102-106

[3]. American Welding Society and the Welding Research Council, Supplement to Welding Journal, March1999, Steady and Pulsed Direct Current Welding with a single Converter. [4]. Welding Equipment Manufacturer Indian Oxygen Limited (formerly), Welding Literatures on Welding Equipment 


\section{BIOGRAPHY}

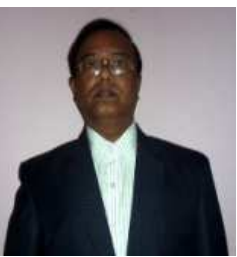

BuddhadevBagchi, M.Tech.(Mechanical),

Govt. Certified Boiler Operation

Engineer.Sr. Dy. General Manager, Power Training Institute, L \& T Power, Vadodara,

Gujarat, India.Ex. Associate Professor,

University of Petroleum \& Energy Studies, Dehradun, India. Ex. Dy. Director, NPTI, MOP, Govt. of India, Durgapur, India.

More than 30 years' experience in Power Sector in the fields of Operation \& Maintenance,Education/Academics in Power Engineering and Designing \& Imparting Training onplanning, designing, erection, commissioning, operation and maintenanceof power plant to the power professionals. Presently engaged with Power Training Institute, L \& T Power for its planning \& development and working in Designing, Planning and conducting Power engineering courses and Training on EPC, Operation \& Maintenance and Planning of Power Sector.Working in various research work for energy efficiency of power plant 